\title{
Governance in energy democracy for Sustainable Development Goals: Challenges and opportunities for partnerships at the Isthmus of Tehuantepec
}

\section{Jacobo Ramirez}

Department of Management, Society and Communication (MSC), Copenhagen Business School (CBS), Frederiksberg, Denmark

\section{Correspondence:}

J Ramirez, Department of Management, Society and Communication (MSC), Copenhagen Business School (CBS), Frederiksberg, Denmark e-mail: jara.msc@cbs.dk
Received: 30 May 2019

Revised: 5 September 2020

Accepted: 15 September 2020

Online publication date: 26 October 2020

\begin{abstract}
This study provides a public policy framework for the governance of energy democracy toward meeting the United Nation's SDGs, and proposes guidelines for policymakers on designing partnerships that promote renewable energy. An increasing number of multinational enterprises (MNEs) and public organizations are prioritizing energy democracy and decarbonization strategies by investing in renewable energy. However, I argue that energy democracy is not "just" about opening up the energy sector to large-scale renewable energy investments. I explore the challenges facing the implementation of energy democracy through a qualitative study conducted from 2013 to 2020 of wind-energy investments at the Isthmus of Tehuantepec, Mexico. A key challenge preventing energy democracy and renewable energy partnerships with indigenous communities at the Isthmus of Tehuantepec is the lack of good governance - corruption, poor accountability, and limited access to information about energy and the environment. Wind-energy investments implemented under the understanding of Partnerships for the Goals may offer sustainable alternatives for reaching the goal of Energy for All and mitigating climate change according to the 2030 Agenda for Sustainable Development. Journal of International Business Policy (2021) 4, I19-135. https://doi.org/10.1057/s422 I4-020-00077-3
\end{abstract}

Keywords: sustainable development goals (SDGs); wind energy; communities; partnerships; governance; energy democracy

\section{INTRODUCTION}

Energy democracy and decarbonization strategies are becoming a priority for an increasing number of governments in the effort to reach clean-energy commitments such as the Paris Agreement and Goal 7 ("Energy for All") of the Sustainable Development Goals (SDGs) (Baker, 2018; Mey \& Diesendorf, 2018; United Nations, 2015a, b, 2016a; van Tulder, 2018). However, different actors policymakers, multinational enterprises (MNEs), and communities 
- have different understandings and views of what is required to reach the SDGs (Avila, 2018; McDermott et al., 2019). In their rush to reach cleanenergy commitments, many governments in emerging markets have introduced a discourse of energy "democratization" by encouraging international business investments (Presidencia de la República, 2012) without integrating local communities' demands (Velasco-Herrejon \& Bauwens, 2020). While this has increased the generation of renewable energy (RE), a lack of partnerships, lack of rule of law, and lack of clear political will for public goods have precipitated mistrust, corruption, and violence (Manzo, 2012). For example, in the Latin American and Caribbean region, there have been 121 allegations of human rights abuses related to RE investments since 2010 (61\% of allegations globally) (Business \& Human Rights Resource Centre, 2020).

Herein, I consider these arguments through the interesting case of wind-energy investments at the Isthmus of Tehuantepec (hereafter Isthmus) in southern Mexico. This region is populated by indigenous peoples whose main socioeconomic activities are agriculture, fishing, and commerce, and has been the focus of many wind-energy projects owing to its excellent wind resources (Manzo, 2012; Rubin, 1994). Mexico has implemented public policies supporting the SDGs (Gobierno de México, 2018) with a particular focus on Goal 7. Energy sector reforms have been gradually implemented through neoliberal public policies since the late 1980s, following the Washington Consensus (Manzo, 2012). These policies facilitated foreign direct investment (FDI) in the energy sector with limited government intervention (Manzo, 2012), positioning Mexico as an ideal country for FDI in RE (Presidencia de la República, 2012), long before it signed and ratified the Paris Agreement in 2016 (United Nations, 2015b). However, Mexico presents large structural vulnerabilities such as corruption and social unrest (PODER, 2015). In addition, new vulnerabilities have emerged since 2018, as the federal government has enacted a series of public policy shifts that have deprioritized $\mathrm{RE}$ investments and reversed energy sector reforms (Secretaría de Energía, 2020).

I argue that a key challenge preventing energy democracy and partnerships with indigenous communities at the Isthmus is the lack of good governance - corruption, poor accountability, and limited access to information about energy and the environment (Baker, 2018; Rothstein, 2012;
Sovacool \& Dworkin, 2015; Szulecki, 2018; VelascoHerrejon \& Bauwens, 2020). I analyze the role of public policies in wind-energy investments at the Isthmus based on the following research questions: What are the challenges of governance in energy democracy in wind-energy investments at the Isthmus of Tehuantepec? and How can we develop partnerships for energy democracy among public organizations, private enterprises, and indigenous communities at the Isthmus of Tehuantepec, building on their experience and resources?

My research makes two important contributions to public policy. First, I extend the current theory of governance in energy democracy by providing a framework for the transition to sustainable energy partnerships, which introduces a novel way of thinking about how decentralized RE models may succeed (or fail) in terms of governance in energy democracy (e.g., Becker \& Naumann, 2017; Sovacool \& Dworkin, 2015; Stephens, 2019; Szulecki, 2018; van Veelen, 2018). Second, I extend research on factors for successful RE programs (e.g., Sovacool, 2013) by proposing key public policies and actions toward energy democracy that MNEs could adopt and that might have long-term implications for capacity building, employment, access to investment and RE, and peace and justice.

This article is structured as follows. The next section reviews the concept of energy democracy and examines the challenges and opportunities for governance in energy democracy. This is followed by the research methodology of the qualitative study that I conducted over the past 8 years. Then, I present my findings on Mexico's public policies concerning the energy sector and climate change and the implications for MNEs and local communities. The discussion and conclusion elaborate on the two main contributions of this research.

\section{LITERATURE REVIEW AND THEORETICAL SCOPE}

\section{Energy Democracy}

Energy democracy is a bottom-up social movement that challenges the centralized monopoly of the energy sector in the transition to RE (Becker \& Naumann, 2017: 4; Stein, 2018: 259; Stephens, 2019). It calls for decarbonization, access to RE, and democratic decision-making (Angel, 2016a; Stephens, 2019; van Veelen, 2018; van Veelen \& Eadson, 2020). The movement emerged in Germany in the past decade out of communities' 
frustration with conventional institutions and political practices (Kunze \& Becker, 2014; Williams \& Sovacool, 2020: 7). It spread quickly in European countries such as Denmark and the UK, which have a long history with participatory RE models such as community RE (Kunze \& Becker, 2014; van Veelen, 2018; Williams \& Sovacool, 2020), and has since gained traction in other developed and emerging markets (Baker, 2018).

The current vision of energy democracy champions decentralized RE sources that are separable from the grid (Stein, 2018: 258), including smallscale RE projects, community-owned programs, and cooperation between communities and MNEs (e.g., Becker, Angel, \& Naumann, 2019). Nevertheless, the frames and constructs of energy democracy may differ in emerging markets from those in Europe and the US (van Veelen, 2018; van Veelen \& van der Horst, 2018). Scholars have discussed the challenges for RE investments in emerging markets in relation to community members' motives, understanding, attitudes toward RE, access to information, participation, and access to finance (Bauwens, 2016; Sovacool, 2013; Ulsrud, Winther, Palit, $\&$ Rohracher, 2015). Theory and research show that energy democracy is embedded in community governance (van Veelen, 2018). Decentralized frameworks can encourage energy democracy through participative decision-making and the fair distribution of benefits in RE production and supply (Stein, 2018; Walker \& Devine-Wright, 2008; Weinrub \& Giancatarino, 2015; Wirth, 2014). The challenges and opportunities regarding the governance of energy democracy in RE investments in emerging markets are presented below.

\section{Challenges and Opportunities in Governance of Energy Democracy}

The principle of good governance is a cornerstone in the energy democracy debate (Rothstein, 2012; Sovacool \& Dworkin, 2015; van Veelen, 2018). Good governance means minimal corruption, rule of law, trust in politicians, improved accountability, transparent decision-making processes, the sharing of high-quality information about energy and the environment, the participation of all people, and ultimately, an overall goal of public goods (Angel, 2017; Rothstein, 2012; Sovacool \& Dworkin, 2015: 439; Szulecki, 2018: 35). It is closely related to Goal 16 of the SDGs: "Peace, Justice, and Strong Institutions." However, in emerging markets, the role of strong institutions is challenged (Doh,
Rodrigues, Saka-Helmhout, \& Makhija, 2017; Luiz, Ganson, \& Wennmann, 2019; McDermott et al., 2019).

Governance in energy democracy is particularly important for RE investments that directly affect communities (Velasco-Herrejon \& Bauwens, 2020). Wind energy is a telling example of this in developed and emerging economies; the building and operation of wind farms requires the conversion of large areas of land (e.g., from agricultural to industrial), which is often owned and/or used by the community and significantly affects those living nearby (Copena \& Simón, 2018; Manzo, 2012; Olson-Hazboun, Krannich, \& Robertson, 2016). In emerging markets, wind farms are often built in poor, rural areas (Shen, 2020) that are inhabited by indigenous communities with a tradition of confronting corrupt governments and blocking MNEs' investments in RE (Manzo, 2012). Changes in land use are a major cause of disputes among communities (Martinez, 2020). These factors may contribute to the reported conflicts among perceived supporters and opponents of RE projects (Avila, 2018; Maher, 2019).

Public policies that integrate local communities are key to diminishing such conflicts in the transition to a decarbonized economy (Clean Energy Council, 2018; Peterson, Stephens, \& Wilson, 2015). Past research on Denmark, Germany, the Netherlands, and Scotland indicates that community RE models lead to positive community attitudes toward wind energy (Toke, Breukers, \& Wolsink, 2008; Weinrub \& Giancatarino, 2015). In addition, mutual trust and cooperation with communities can give MNEs a competitive advantage because certain communities have knowledge or resources that MNEs require (Doh et al., 2017; Madriz-Vargas, Bruce, \& Watt, 2018). However, a lack of governance in energy democracy may hinder opportunities for community participation (Sovacool \& Dworkin, 2015; Szulecki, 2018).

There have been limited discussions of how public policy should be devised to meet climate and energy justice movements and of what energy democracy would look like in emerging markets (Angel, 2016b; Baker, 2018; Jenkins, 2018; Sovacool, 2013). Understanding the role of governance in energy democracy and the implications of public policies for MNEs and indigenous communities may facilitate the transition to a decarbonized energy sector. 


\section{METHODS}

I collected information on Mexican public policies and reforms implemented from 1992 to 2020 that concerned the energy sector and climate change. I then conducted three roundtable discussions (focus groups) and unstructured interviews with thirty different actors from 2013 to 2020 (see Table 1) to explore and understand the implications of these public policies for MNEs and local communities at the Isthmus. The actors included government officials from Mexico, Denmark, and the Netherlands; representatives from the European Union; managers from MNEs involved in wind projects; private organizations investing in wind-energy; NGO representatives; and members of local communities from the Isthmus, including indigenous people. I purposefully sampled the interviewees (Patton, 2002) by approaching organizations and individuals who were especially knowledgeable or experienced in public policy affecting Mexico's energy sector, FDI in wind energy, and communities living near wind farms.

The topics covered in the interviews and roundtable discussions were tailored to gauge actors' reactions to Mexico's energy public policies and the development of wind parks at the Isthmus; actors' visions regarding wind-energy investments and energy democracy; MNEs' motivation and challenges in wind-energy investments at the Isthmus; details of the consultation process (or lack thereof); the implications for indigenous communities' socioeconomic activities; and the relationships and conflicts among different actors.

Given the sensitivity of the issues involved, I could not record the primary data collection; however, I took notes during all my interactions and transcribed them after each meeting. All interactions took between $15 \mathrm{~min}$ and $2 \mathrm{~h}$. Owing to the COVID-19 pandemic, interviews that took place in 2020 were held online (e.g., Microsoft Teams, WhatsApp, and Zoom), with additional e-mail correspondence.

I also systematically downloaded approximately 1000 news reports on wind energy; monitored 47 webpages from which I took notes on indigenous peoples' protests; and analyzed 52 reports on wind firms' sustainable investments, business and human rights, and wind energy in Mexico. Furthermore, I analyzed Mexico's online platform (https://www.agenda2030.mx) for tracking progress toward achieving the SDGs (Gobierno de México, 2018).

\section{Empirical Material Analysis}

I organized the empirical material using NVivo11 (qualitative software). My experiences as a researcher are naturally partial and incomplete; hence, to ensure the quality of the empirical material (Patton, 2002), I triangulated the data with previous research on the Isthmus' indigenous people (e.g., Manzo, 2012; Martinez, 2020; Rubin, 1994). The triangulation process was used to compare, contrast, and complement my informants' inputs with external documents. This process helped me develop a broader understanding of wind farms at the Isthmus and public policies concerning RE, which I postulated might be factors in facilitating or preventing community partnerships.

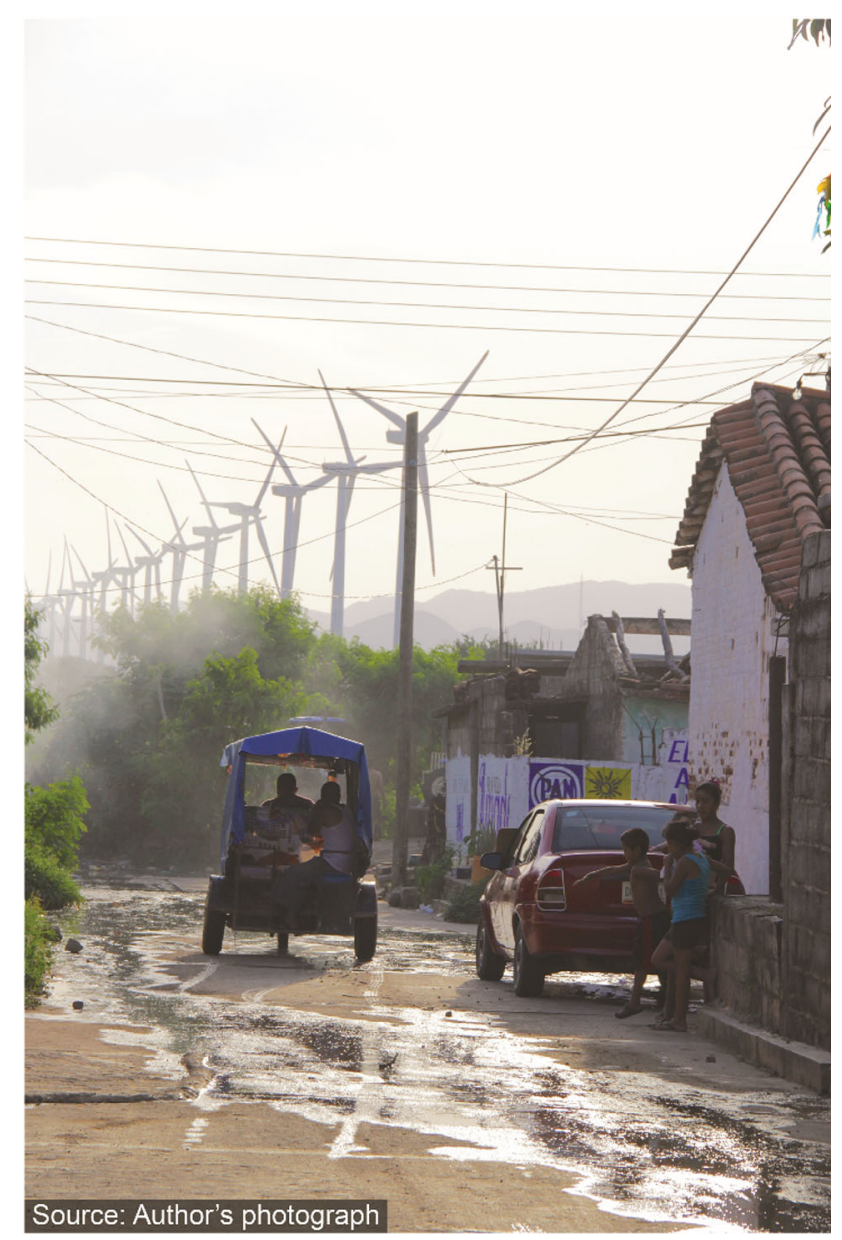

Figure 1 Lack of basic infrastructure at Juchitán-Isthmus of Tehuantepec. 
In the first stage of analysis, I analyzed public policies implemented in Mexico between 1992 and 2020 that concerned the energy sector and climate change to identify crucial constitutional reforms, laws, and regulations. I then queried the interviewees about the implications of such reforms and integrated their observations into my analysis (see Table 2). This was an ongoing process because new public policies were enacted in Mexico after the initial round of interviews held in 2013 (see Table 1).

In the second stage of analysis, I developed interpretations by reanalyzing my observations, narratives from empirical material, and past research. I clustered such narratives to further analyze the different perspectives on features of governance in energy democracy that might influence actors' partnerships toward reaching Goal 7. This process was interactive, beginning at the microlevel of indigenous people's responses to MNEs' sustainable energy investments and government public policies in pursuit of SGDs. I analyzed four related practices of good governance: information sharing, transparency, public goods, and human rights (Rothstein, 2012; Sovacool \& Dworkin, 2015; Szulecki, 2011; van Veelen, 2018).

\section{FINDINGS}

\section{Public Policies for Sustainable RE Development in Mexico, 1990-2020}

Mexico is traditionally an oil-producing country. However, since the 1990s, the Mexican government has gradually implemented a comprehensive legal and institutional framework through neoliberal public policies for its transition to RE (see Table 2). In 2000, the election of President Vicente Fox Quesada marked the end of 71 years of uninterrupted rule by the Institutional Revolutionary Party (PRI). Fox quickly identified the state of Oaxaca as "abandoned" and "underdeveloped" (Aznarez, 2001), leading to its inclusion in the Plan Puebla Panama mega-project to open it up to FDI in wind energy. Fox's successor, Felipe Calderón Hinojosa, advanced a powerful discourse of sustainable development, pushing toward "energy democracy" and a "green economy" with urgency (Field Notes; Presidencia de la República, 2012).

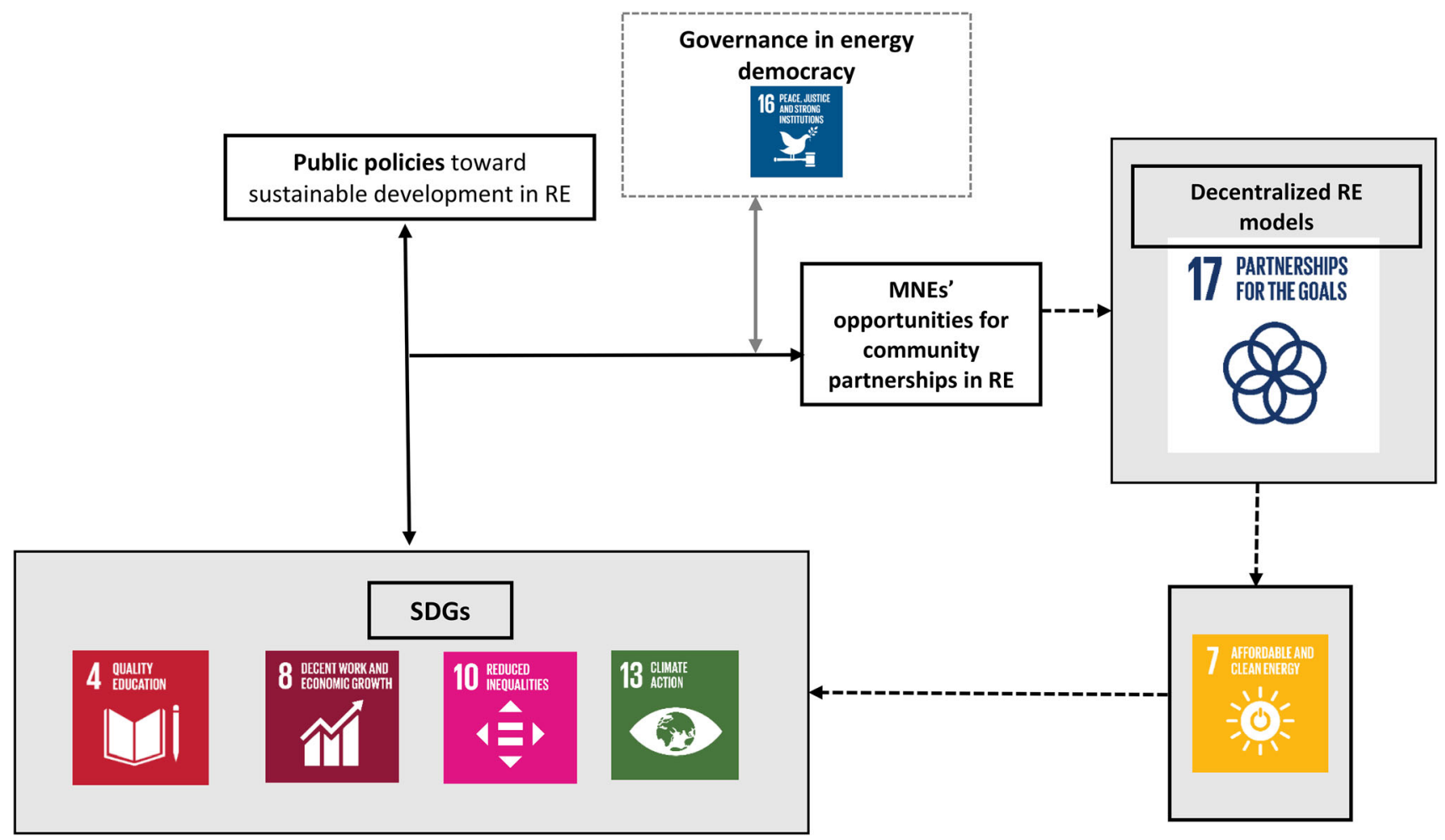

Figure 2 Framework for transitioning to sustainable energy partnerships. 
Various laws, regulations, and endorsements of international conventions to help investors proceed with wind-energy projects were established during Calderón's presidency (Table 2). In 2013, a constitutional energy reform was undertaken that financially incentivized RE investment in the form of carbon bonuses (Gobierno de México, 2018; Interviewee 8). These incentives appealed to organizations seeking to invest in RE projects amid pressures to move away from carbonized investments and the rise of "carbon offsetting," and positioned Mexico as a "hot country to invest in
RE" (Interviewee 22; Table 2). A manager at a Dutch fund explained their motives for investing in RE in Mexico as follows:

We have pressure from our members to move our investments from carbonized energy such as oil and gas into RE. This is the reason for our "adventure" to invest Dutch pension funds in wind-energy projects in Mexico [Isthmus]. (Interviewee 16).

Many wind-energy developers based their projects at the Isthmus. By 2019, there were 2447 wind turbines in Mexico, with 1600 of these located

Table 1 List of interviewees

\begin{tabular}{|c|c|c|c|c|c|}
\hline No. & Position/Profession & Organization & $\begin{array}{l}\text { Country of } \\
\text { interview }\end{array}$ & Nationality & $\begin{array}{l}\text { Year of } \\
\text { interview }\end{array}$ \\
\hline 1 & Roundtable participants & Members of the Communal Assembly & Mexico & Zapotec* & $\begin{array}{l}2013,2015, \\
2017\end{array}$ \\
\hline 2 & Consultant & Green Energy Consultancy Firm & Germany & German & 2013 \\
\hline 3 & Fisherman & Self-employed & Mexico & lkoot* & 2013 \\
\hline 4 & $\begin{array}{l}\text { Oaxaca State Secretary of } \\
\text { Indigenous Affairs }\end{array}$ & Oaxaca Government & Mexico & Mexican & 2013 \\
\hline 5 & $\begin{array}{l}\text { Corporate Social Responsibility } \\
\text { Director }\end{array}$ & European wind firm & Denmark & Danish & 2013 \\
\hline 6 & Diplomat & $\begin{array}{l}\text { Embassy of The Netherlands in } \\
\text { Mexico }\end{array}$ & Mexico & Netherlands & 2013 \\
\hline 7 & Fisherman & Self-employed & Mexico & lkoot* & 2013 \\
\hline 8 & Commercial Advisor & Embassy of Denmark in Mexico & Mexico & Danish & 2015 \\
\hline 9 & Technical Sales Management & European wind firm & Mexico & Mexican & 2015 \\
\hline 10 & Human Rights Defender & Communal Assembly & Mexico & Zapotec* & 2015 \\
\hline 11 & Social Relations Manager & European Wind Firm & Mexico & Mexican & 2015,2017 \\
\hline 12 & Commercial Advisor & Mexican Government & Mexico & Mexican & 2015 \\
\hline 13 & $\begin{array}{l}\text { Trade and Investment } \\
\text { Commissioner }\end{array}$ & $\begin{array}{l}\text { Government Agency for Trade and } \\
\text { Investment }\end{array}$ & Denmark & Mexican & 2015 \\
\hline 14 & Human Rights Defender & Communal Assembly & Mexico & Zapotec* & 2016,2017 \\
\hline 15 & Commercial Advisor & Trade Council: Government Agency & Mexico & Danish & 2017 \\
\hline 16 & Public Relations Manager & Pension Fund Organization & Switzerland & Dutch & 2017 \\
\hline 17 & Engagement. Advocacy Campaigns & $\mathrm{NGO}$ & Switzerland & Mexican & 2017 \\
\hline 18 & Farmer & Self-employed & Mexico & Zapotec* & 2017 \\
\hline 19 & $\begin{array}{l}\text { Deputy Director \& Head of Europe } \\
\text { Office }\end{array}$ & NGO & Switzerland & British & 2017 \\
\hline 20 & Financial Advisor & IADB & Denmark & Spanish & 2018 \\
\hline 21 & Coordinator Environment \& Climate & NGO & Denmark & Danish & 2019 \\
\hline 22 & Consultant to the Americas Market & Enterprise Association & Denmark & Danish & 2019 \\
\hline 23 & Senior Manager & NGO: Community Relations & Switzerland & Argentinian & 2019 \\
\hline 24 & $\begin{array}{l}\text { Deputy Trade and Investment } \\
\text { Commissioner }\end{array}$ & $\begin{array}{l}\text { Government Agency for Trade and } \\
\text { Investment }\end{array}$ & Mexico & German & 2019 \\
\hline 25 & Investment Director & Investment Fund Agency & Denmark & Danish & 2019 \\
\hline 26 & Director Energy and Sustainability & Mexican MNEs & Mexico & Mexican & 2019 \\
\hline 27 & Head of Sustainable Performance & Multinational Corporation & Denmark & Danish & 2020 \\
\hline 28 & $\begin{array}{l}\text { Head of Economic and Cooperation } \\
\text { Section }\end{array}$ & Embassy of Mexico in Denmark & Denmark & Mexican & 2020 \\
\hline 29 & Responsible Partners Program & European Wind-Energy Developer & Denmark & Danish & 2020 \\
\hline 30 & Activist and Reporter & Self-employed & Mexico & Zapotec* & 2020 \\
\hline
\end{tabular}

*Indigenous Mexicans. 


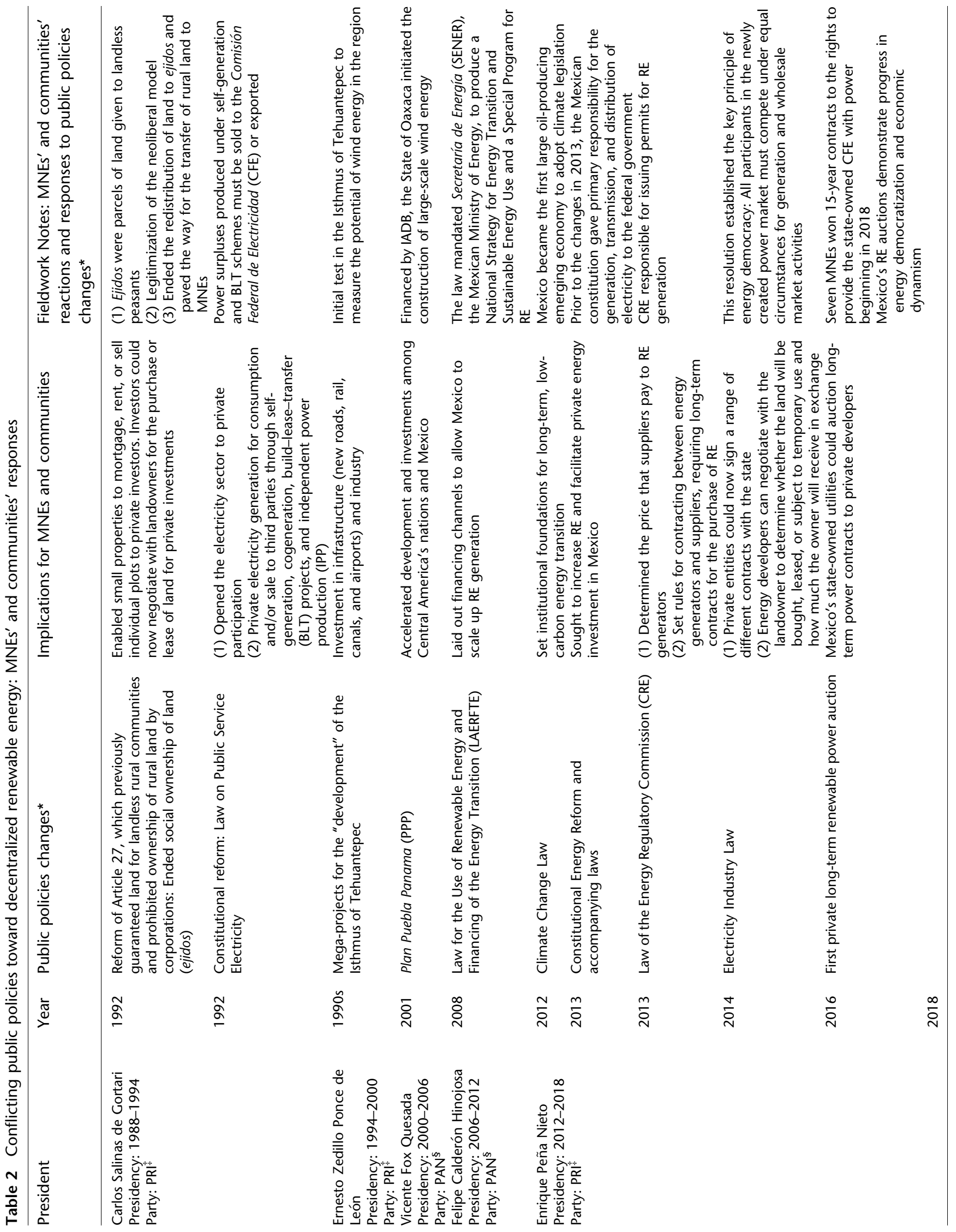


across 32 farms on the Isthmus (Asociación Mexicana de Energía Eólica (AMDEE) [Mexican Wind Energy Association], 2019). Wind turbines in this region accounted for approximately $62 \%$ $(2756 \mathrm{MW})$ of the total wind energy produced in Mexico in 2020 (Zavala, 2020). The Ikoots and Zapotecs (indigenous peoples from the Isthmus) have had conflicting responses to Mexico's RE transition, as presented below.

\section{Challenges for Governance in Energy Democracy} at the Isthmus of Tehuantepec

In the 1980s, Zapotecs surprised Mexico and the rest of the world when Juchitán - the head of the municipality at the Isthmus - democratically elected a socialist party - Coalition of Workers, Peasants, and Students of the Isthmus (COCEI) to run the local municipality (Rubin, 1994). This sent a strong message to the technocratic market-oriented PRI party that had ruled at the local and state levels since 1929 (Field Notes). MNEs and government officials often have different understandings of wind investment and the eventual spillover effects on local communities. Although some community members at the Isthmus are open to developing partnerships with MNEs in wind-energy projects, others are mistrustful of MNEs and the government and reject the prospect of wind-energy investment owing to the failure for over 20 years to consider the perspectives of local indigenous communities when planning and building wind parks (Roundtable, 2013). These community members seek to defend their territories and preserve their languages, traditions, and customs, often by fighting, resisting, and pursuing justice (Field Notes; Routable 2015). Below, I present some of the most salient challenges (as per Goal 16) in wind-energy investments (as per Goal 7).

\section{Lack of information and transparency}

Inclusive and transparent decision-making is a key characteristic of good governance in energy democracy (Rothstein, 2012; Sovacool \& Dworkin, 2015; Szulecki, 2018). The roundtable discussions revealed that wind-energy investments at the Isthmus have been marked by a lack of participatory governance and democratic engagement with members of civil society (Roundtable, 2013, 2017). Public consultations for RE were only written into Mexican legislation in 2014 under the Electric Industry Law (see Table 2). Under this legislation, energy developers must inform both the property owners and the Mexican energy 
secretary of their proposed plans (Electric Industry Law, Article 73). This appears to be in accordance with Indicator 16.10 of Goal 16: Ensure public access to information and protect fundamental freedoms, in accordance with national legislation and international agreements (United Nations, 2016b). However, in many cases, public consultations were held only after the approval of FDI by the Mexican federal government (Interviewee 12; Roundtable, 2013), suggesting that consultations were not "prior" as stipulated by "free, prior, and informed consent" principles of ILO Convention 169 (International Labour Organization, 2017). It appears that public consultations were held only to meet the requirement of the law and not to actually discuss the project or gauge community opinion (Roundtable, 2015).

NGO reports, news reports, and interviews indicated that local communities have limited access to important information regarding the development, potential effects, and financial aspects of windenergy investments (Interviewee 17; PODER, 2015). Consultations about wind projects at the Isthmus were held with local communities for the first time in 2014 and 2015 and involved sharing information regarding the construction process; the functioning of wind turbines; job creation in the construction process; myths and realities regarding wind turbines, such as health and noise; environmental impacts; and the economic importance of the investments (Centro de Colaboración Cívico, 2015, see Table 2; Field Notes). No information regarding project financing, taxes paid to state and local governments, or corporate profits was provided (Roundtable, 2015). This lack of specific financial information fostered skepticism in local communities, fueled by their experiences with the corrupt practices of local government officials (Field Notes). For example, the mayor of San Mateo del Mar - a municipality in which some of the consultations were held - falsified the assistance list to meet the minimum requirement stipulated by the Mexican laws and ILO Convention 169 for the number of local communities agreeing to land use change from agricultural to industrial (Field Notes; Roundtable, 2013; Interviewees $7 \& 18$ ).

The failure to provide actionable information in a timely and coherent manner has, unsurprisingly, created mistrust toward MNEs among members of local communities at the Isthmus; much suspicion of corruption and dishonesty exists (Interviewee 14, 2017). According to the data collected, multiple local communities perceive public consultations as a means of forcibly acquiring communal land for strategic projects to mitigate climate change (Roundtable, 2017; Table 2). A fisherman in San Mateo del Mar expressed, "If so much money is being invested in the region...then why are so few members of local communities actually seeing it?" (Interviewee 7).

\section{Lack of public goods: education, jobs, and access to $R E$}

The Mexican government, wind-energy developers, and businesses investing in the Isthmus region argue that transforming unproductive land through the installation of wind turbines brings jobs and development to the region (Manzo, 2012). More than 20 years have passed since Mexico began implementing public reforms to open its energy sector to FDI (see Table 2), yet some communities at the Isthmus still lack basic infrastructure, such as paved roads, drains, purified water, access to RE, and Internet access (Field Notes, see Figure 1). The quality of education is also lacking; of the communities I visited, many lacked basic literacy skills (Field Notes). Study programs for the Isthmus do not provide basic education on how the transition from burning firewood for cooking and heating purposes to RE would help reduce health hazards and carbon emissions (Field Notes). The visited communities had not heard about the SGDs. For example, an interviewee commented, "[The SDGs] sound good, but I don't know what [they are] about" (Interviewee 3 ).

Wind-energy MNEs and investors have implemented programs for the well-being and social development of communities living near wind parks on the Isthmus, including the construction of a community football court; summer courses on environmental education, health and sports; and a culture of peace (Asociación Mexicana de Energía Eólica (AMDEE) [Mexican Wind Energy Association], 2020). Nevertheless, these social development programs are individual efforts that lack coordination among local communities, municipalities, and other MNEs (Field Notes). Little effort has been made to develop local skilled workforces to work on wind farms (Interviewee 4). Interviewees tended to agree that there is limited capacity at the Isthmus to research, develop, and manufacture RE technologies, including wind energy (Interviewee 26). Many components for RE projects are imported, mainly from Europe (Interviewee 9). Ultimately, news reports indicated that by 2012 , 
employment rates at the Isthmus had decreased because agricultural land was leased to wind-energy developers (e.g., Beas-Torres, 2012) - a stark contrast from the promised development and jobs.

\section{Heterogeneous communities and human rights}

In general, the indigenous communities I visited are not against RE investments. They are concerned about the impact of climate change on their socioeconomic activities (e.g., agricultural and fishing), particularly diminished production (Field Notes). Nevertheless, they are against the process in which wind-energy investments have been conducted in their region and the lack of access to participation (Field Notes; Interviewee 30; Routable 2013, 2015). During my research, I gradually identified that the local communities were divided into three groups: (1) community members who own land and want to keep leasing it to windenergy developers; (2) communities that want to continue participating in wind-energy developers' social programs; and (3) communities that reject wind-energy investments (Field Notes). The division of local communities has evolved into social conflicts between the opponents and supporters of wind-energy investments at the Isthmus. The desire for peace in the region was a recurrent narrative in my investigation. A local resident commented that they "do not want narcos, violence and crime; [they] just want to keep working as [their] ancestors did in fishing and agricultural activities and defending [their] territory" (Interviewee 18). Disputes among communities often descended into violence, conflict, and human rights abuses (Business \& Human Rights Resource Centre, 2020). According to the Mexican Center for Environmental Law (Hernández, Cerami, Bartolo, Hernández, \& Ceballos, 2017), between July 2015 and July 2016, there were 35 attacks against human rights defenders related to mega-projects and other wind-energy investments in Oaxaca. One assassination was registered in 2013 and another in 2016 in relation to wind-energy projects, with eight human rights violations in 2015 and four in 2016, including intimidation, criminalization by physical aggression, harassment, defamation, and illegal deprivation of liberty (Roundtable, 2017).

The Mexican Constitution presents accountability procedures to protect the human rights enshrined in international treaties and recognizes social and economic rights (Cámara de Diputados del H. Congreso de la Unión, 2011). However, when human rights abuses related to wind-energy investments in Oaxaca were reported to officials, local police forces failed to respond (Field Notes). According to the data collected, in municipalities such as San Mateo del Mar, protestors of windenergy developments have reportedly been jailed as one activist and journalist described it, "Local police forces protect wind-energy projects and not local communities" (Field Notes, Interviewee 30). This has fueled local conflicts that continue to this day; in June 2020, 15 people were killed in San Mateo del Mar in relation to these disputes (The Guardian, 2020). Although public policies implemented in Mexico since the 1980s aimed to democratize the energy sector, it is a dangerous place to be a human rights defender - more dangerous than any other country in the world (Human Rights Council, 2018).

In contrast to the continued human rights abuses related to wind-energy developments, MNEs have publicly conveyed that their practices respect human rights. For example, one MNE's website stated the following:

\begin{abstract}
...[our organization] expects its business partners to respect human rights and will take measures to promote responsible practices...in relation to our organization's value chain. Our firm will identify and consult with the local people whose human rights might be impacted by our operations, including engaging in dialogue with local communities to identify and address any human rights risks and opportunities (President and Chief Executive Office of a European wind firm [website], 2014).
\end{abstract}

The good intentions of MNEs appear to conflict with the lack of good governance in wind-energy investments at the Isthmus concerning public consultations and the protection of human rights defenders.

\section{Lack of partnerships}

Although MNE representatives have deployed resources (e.g., via corporate social responsibility) to ensure positive engagement with local communities, these investments seem to be understood differently by local communities (Asociación Mexicana de Energía Eólica (AMDEE) [Mexican Wind Energy Association], 2020; Field Notes; Roundtable, 2017). Representatives of communal assemblies at the Isthmus express an "unwillingness to participate in any kind of partnership model to provide consent to further wind-energy investment in their communities" (Interviewee 14, 2016). A member of the Assembly of the Indigenous Peoples stated the following: 
We do not believe that [wind farms] will offer any of the benefits that the politicians and foreign firms claim our communities would receive. [MNEs] want us to lease our land on unfair terms... It's abusive. (Interviewee 3).

According to the collected data, an important aspect of successful wind investments is the development of partnerships for the democratic participation of local people: "The critical point is participation. People want to participate directly in decision-making, planning, implementation, and managing" (Interviewee 4). Local communities' expectations for participation appear to conflict with the expectations of governments and MNEs. Different explanations exist for this. Given the lack of peace and justice in Mexico, trust among communities and wind-energy developers is limited (Interviewee 4). Local and international NGOs have guided local communities to defend their rights and lectured them about community partnership schemes in Europe (Interviewee 23). For example, in Germany, wind farm construction generated competition among farmers to rent their land to developers (Interviewee 2). It appears that some indigenous people aspire to do business with MNEs as equals. A member of the local assembly commented, "We have the land, and [MNEs] have the technology, so I believe that we can do business together" (Interviewee 10).

Based on this specific statement, I asked an executive from a European wind MNE whether they plan to integrate indigenous people as key partners. The executive commented:

\begin{abstract}
...the other part of the story is that [indigenous people] do not envision or their leaders who give them that information [on partnership schemes] do not tell them that yes, of course [you have the land]; but where is a wind turbine manufactured? Well, in Europe... Wind-energy projects are more complex than [indigenous people] can imagine. (Interviewee 11, 2015).
\end{abstract}

The government, businesses, and financial institutions appear to view partnerships with local communities as "irrelevant" and "nonpragmatic" for wind energy in Mexico (Interview 26; Roundtable, 2017). As one interviewee noted with concern, "Local communities cannot understand the complexities involved in wind investment in relation to financing, the technology involved, and the construction itself. It is not pragmatic to involve local communities in these processes" (Interviewee 9). A wind-energy developer commented, "We are not the owners of the projects, we 'just' build the wind parks, so we cannot make the decisions about involving local communities as active partner in a project" (Interviewee 11, 2017). The pertinent question is finance: how can local communities access financing for RE projects, such as from the IADB? An IADB representative critically commented, "A guarantee for communal RE projects has to be provided; if the Mexican government could provide such a guarantee, we would be happy to finance a community-owned wind-energy project" (Interviewee 20). However, Mexican law does not establish a framework for possible cooperative schemes (see Table 2). In 2012, local communities of Ixtepec on the Isthmus were motivated to participate in a community wind-energy project to mitigate climate change and protect their livelihoods (Field Notes; Roundtable, 2013). The community, in collaboration with a European NGO, solicited the Mexican government through the state-owned electricity firm CFE (Commisión Federal de Electricidad) to provide credit to build a wind farm in the city of Tehuantepec (Roundtable, 2013). The inquiry never progressed. An executive from a wind MNE commented that "...it is hard for [indigenous people] to understand the huge investment involved in this project" (Interviewee 11, 2017).

The well-intended strategies implemented by MNEs and the public policies developed in Mexico seem to be understood differently by local communities, which might be a source of the conflict that has erupted in the region. Unfortunately, the conflict itself seems to damage the possibility of partnerships. An MNE director of energy and sustainability stated:

\footnotetext{
...Local communities protesting against MNEs' investments are motivated to show their frustration against the local, state, and federal governments, particularly in Oaxaca. This is the reason that some investors don't want anything to do with local communities. (Interviewee 26).
}

Mexico's context is vastly different from many other economies transitioning to RE (Mey \& Diesendorf, 2018; Interviewee 2). Despite the introduction of public policies for Mexico's energy transition, in reality, carbonized energy production and consumption continue. The federal government in control since 2018 has canceled many RE bids/auctions for new RE investments. In 2020, the Secretaría de Energía (SENER) [Ministry of Energy] proposed a new policy based on the intermittency of RE, named "Reliability, Security, Continuity and Quality in the National Electric System" (Secretaría de Energía, 2020). This policy establishes that 
public transmission and distribution services are strategic areas of the government of Mexico and are necessary for maintaining energy security and independence. The policy establishes new controls to guarantee the supply of electrical energy. However, the policy generated strong criticism and public pronouncements from the private sector (see Table 2). The proposed policy was rationalized as follows:

\footnotetext{
The government's objective in the field of electricity generation is to strengthen CFE's monopoly and reduce competition in the electricity market. The Mexican government wants to increase its dependence on conventional generation, including domestic natural gas and hydroelectric power. (Interviewee 28).
}

Energy democracy is a contentious "window-dressing" framework that appears to be implemented in the context of this research as the decentralization of the energy sector, without considering indigenous peoples' voices. These arguments are elaborated in the following section.

\section{DISCUSSION}

Wind-energy investments at the Isthmus present contradictory tendencies in their governance of energy democracy (e.g., Becker \& Naumann, 2017; Szulecki, 2018). Public policies and constitutional reforms have been implemented to decentralize the Mexican energy sector by promoting large-scale wind-energy investments from national and foreign MNEs based on the technocrat premises of the Washington Consensus (Table 2). However, such reforms fail to integrate communities' demands for participation in decision-making processes. This might be the most basic form of community participation in energy democracy. The lack of good governance regarding information sharing, transparency, public goods, and human rights (Rothstein, 2012; Sovacool \& Dworkin, 2015; van Veelen, 2018) appears to limit partnerships and create a source of conflict and discontent among local communities (Maher, 2019). Below, I elaborate on the challenges of governance in energy and propose an alternative to develop partnerships for energy democracy in the context of this research.

\section{Challenges in Energy Democracy}

Relational partnerships based on trust and cooperation could be key for attaining the SDGs (Kowszyk \& Maher, 2018; van Tulder, 2018; van Zanten \& van Tulder, 2018). Our understanding of energy democracy from Europe (e.g., Angel, 2017; Szulecki,
2018; van Veelen \& Eadson, 2020) can be extended by recognizing that democracy has a different connotation in the context of this research. The communities I consulted demand access to information and meaningful participation in complex decision-making processes for wind-energy investments, and they aspire to live peacefully in a society where public policies are respected, as per Goal 16. At the same time, some aspire to participate in RE partnership agreements. This conflicting interest among local communities, MNEs, and local government is problematic. If the current laws and legislation were followed, the specific type of partnerships could be discussed among communities and firms. Such discussion might help to integrate communities' demands while transforming the energy sector and securing energy democracy.

This study supports previous research on the dynamics of conflict among local communities derived from RE investments (Avila, 2018; Maher, 2019; Manzo, 2012). This emerging finding has rarely been discussed in the theory and research on governance in energy democracy beyond Europe (Angel, 2017; Baker, 2018). Thus, the first contribution of this research to public policy is an extended understanding of governance in energy democracy through a framework for a transition to sustainable energy partnerships (see Figure 2). This framework introduces a novel way of thinking about how decentralized RE models may succeed (or fail) in terms of governance in energy democracy (e.g., Becker \& Naumann, 2017; Rothstein, 2012; van Veelen, 2018).

Governance in energy democracy provides an opportunity to transform the energy system in line with the SDGs. As indicated in Figure 2, the design and implementation of decentralized RE models for partnerships in RE (Goal 17) that consider the context and needs of different communities are facilitated when public goods such as quality education (Goal 4), RE (Goal 7), decent work (Goal 8), reduced inequalities (Goal 10), and climate action (Goal 13) are in place against a backdrop of strong institutions (Goal 16). However, without good governance, the prospects of partnership RE models are limited, as illustrated by the gray dotted line in Figure 2. In short, without good governance in energy democracy (see Figure 2), it is challenging for MNEs to start a dialogue with the local communities that are willing to engage in wind-energy partnerships. Given the challenging social fabric at the Isthmus, where there is widespread corruption, 
lack of accountability, impunity in protecting local communities and human rights defenders, and mistrust within communities as well as toward MNEs and local, state, and federal governments, there is a need to invest in "good" governance. Good governance in energy democracy might help to restore trust and cooperation with local communities. It is my hope that human rights abuses attributed to wind-energy investments at the Isthmus might decrease as principles of good governance in energy democracy are implemented in the region. This might be a stepping-stone toward a dialogue with the communities that reject any kind of interaction with government officials and MNEs.0

The global energy transition offers an unprecedented opportunity for transformation across political, social, and economic dimensions (e.g., Baker, 2018; Williams \& Sovacool, 2020). I posit that Mexican technocrat policymakers missed an opportunity to transition toward good governance in energy democracy by enforcing basic principles stipulated in the SDGs (e.g., Goal 16) and then devising public policies aligned with energy democracy. Decentralization of the energy sector is not "just" opening the energy sector for MNE investments; decentralization needs to integrate the principles of good governance into energy democracy. For example, the earliest conceptualization of energy democracy states that "energy production must...neither pollute the environment nor harm people" (Kunze \& Becker, 2014: 8). In the European context [Denmark and Germany] in which it originated, this implies the avoidance of disasters such as Chernobyl; elements of good governance are taken for granted (e.g., Stein, 2018). In the context of this research, "nor harm people" is related to basic principles of human rights such as peace (e.g., Szulecki, 2011). This leads to a contradiction in Mexico, as public policies are presented and promoted as energy democracy; however, they do not integrate communities' demands or needs the very definition of energy democracy in Europe. Although the technocratic transition to RE or the notion of "development as a threat to tradition" might seem to jeopardize wind-energy investments, and although this might be the case in Europe, it is not true in Latin America, as shown at the Isthmus.

The SDGs were agreed upon by nation states (United Nations, 2015a). My findings challenge the SDGs by suggesting that Goal 17, among others, is naïve in its lack of consideration for the more fundamental interests of key actors - local communities - such as stronger institutions, as presented in Goal 16. I posit that the objective of Mexico's energy transition was not community wellbeing, but large-scale RE investment framed as "democratization" (Table 2). In the context of this research, the public policies to reach Goal 7 were implemented using a top-down approach. Good governance in energy democracy requires the recognition and involvement of indigenous communities and consideration for customary laws and other nonstate forms of rulemaking at global to local scales (McDermott et al., 2019: 510). Indigenous people are becoming more relevant key actors; they have begun to make their voices heard in rejecting technocrat public policies and vindicating their own modes of existence, organization, and rights (Business \& Human Rights Resource Centre, 2020). As suggested in Figure 2, focusing on Goal 7 without a holistic approach to considering communities' demands appears to be insufficient for achieving the SDGs.

Based on the analysis from this research, the following section offers an alternative transition path toward a decarbonized society and the pursuit of the SDGs.

\section{MNEs' Opportunities for RE Partnerships with Local Communities}

Although Mexico's public policies to promote FDI in RE may decarbonize the existing economy, they are unlikely to transform it. To transform the energy structure and reach energy democracy, a much more profound transformational change is required that would affect the political, social, cultural, and economic environments on a daily basis (e.g., Gevorkyan, 2018). The transformation to energy democracy requires a long-term approach with suitable legislation, governance, and MNE support. MNEs could play a key role in attaining the SDGs, such as by transferring the successful principles of community RE models from Europe to emerging economies. Governments and MNEs need to "apply their creativity and innovation to solving sustainable development challenges" (United Nations, 2015a: 29). Decentralized RE models toward Goal 7 will help mitigate climate change, as per Goal 13, and assist MNEs in contributing to Goals 4, 8, 10, 16, and 17 (Figure 2). Thus, the second contribution of this study is to extend the factors involved in the success and failure of RE programs (Sovacool, 2013) by proposing key public policies and business actions for governments and 
MNEs, as indicated by the dashed arrows in Figure 2.

1. Expansion of education, training, and development programs in RE (SDG 4): Currently, communities are not familiar with the benefits of RE. It is necessary to help them learn and discuss how people interact with energy. Public policies should be developed to integrate sustainable development and RE into elementary to higher education. Technical and engineering higher education programs and RE training are required to create local skilled workforces.

a. Public policies should be designed to create funding systems that provide incentives for institutions and students to access RE education, such as scholarships, grants for living expenses, and student loans.

b. MNEs should work with local educational institutions and policymakers to develop suitable RE education programs.

2. Promote employment through RE (SDG 8): MNEs should develop and promote local employment in RE by implementing training and internship programs targeting local communities and connecting students with the local RE labor market.

3. Improving access to $\mathrm{RE}(S D G \quad 7,10$ \& 13): Financial incentives exist for MNEs to invest in $\mathrm{RE}$; moreover, incentives should be created to encourage end consumers to access RE to reduce greenhouse gas emissions. Inequalities in RE access could be targeted through the following:

a. Financial services to motivate end users to replace traditional biomass cooking systems with modern RE-powered stoves.

b. Financial support through tax incentives for RE consumption.

4. Ensuring compliance with laws and regulations (SDG 16): Binding mechanisms are needed to ensure that governments and MNEs comply with existing national and international laws and regulations on RE investments.

5. Fostering accountable and transparent governments (SDG 16): Public policies at the federal, state, and municipal levels should facilitate the sustained dissemination of information on national $\mathrm{RE}$ developments to help local communities build trust in the government and make informed choices.

6. Renewable ownership (SDG 17): Public policies should encourage the participation of local communities beyond public consultations, as presented in the Electric Industry Law and ILO Convention 169. Coownership with local communities should be incentivized, along with community ownership. Coownership constitutes a new form of participation in emerging markets committed to an RE transition.

a. Funding could help communities develop RE projects such as wind farms. This could lead to stakeholder partnerships in RE investments among financial institutions, MNEs, local governments, and local communities.

b. MNE partnership programs with local communities in decentralized RE models could function as an indicator of MNEs' actions toward the SDGs.

A long-term approach to implementing these proposals could elicit a transformation to an ecologically sustainable economy. If all actors worked together, the poor governance patterns in energy democracy could be reversed. Community RE models could be an opportunity for MNEs to mobilize local communities' existing resources, such as knowledge of trade, commerce, and collaboration.

\section{LIMITATIONS}

Although this research focuses on the specific context of the Isthmus, the human and development demands of local communities described herein echo the silent voices of those in developed countries who feel left behind because of large-scale energy investments and those who experience increased inequalities and climate change impacts. This study presents a number of limitations. Access to additional groups would likely have provided a different perspective from the findings presented herein. In addition, I relied on a local translator to converse with the Ikoots and Zapotecs indigenous peoples; the translator was not a professional interpreter, which might have led to misinterpretations in the conversations. 


\section{Implications and Future Research}

Energy reforms in Mexico for decentralized RE could encourage partnerships among wind firms, investors, and local communities. Community RE models, such as those implemented in Latin America or Asia, could serve as a rationale for policymaking (Madriz-Vargas et al., 2018; Sovacool, 2013). European businesses and governments that have implemented community RE models could be a source of inspiration for new wind investments in developed and emerging markets. Businesses and local governments could implement a decentralized model with strong democratic energy governance at all levels, which could foster community empowerment and capacity, particularly in understanding RE (technical issues) and financial capacities. Thus, public policies should allow both collective and individual participation to challenge existing energy expenditures and shift public resources and institutional investments toward new investment models for community ownership (Burke \& Stephens, 2018). Future research could examine how businesses and governments manipulate national laws and international conventions to obtain RE investments. This study presents an empirical analysis of how a government can facilitate centralized FDI models while failing to provide good governance in energy democracy.

\section{CONCLUSION}

Investing in wind energy may be key to ensuring modern and affordable energy for all; mitigating climate change; and enhancing education, inclusive employment, and good governance in energy democracy. SDGs for a better world could be achieved through partnership models in sustainable development projects. Public policies should provide a platform for partnerships with marginalized people, such as through community RE models. This study should help policymakers redesign existing laws and international trade agreements and conventions to help both emerging and developed economies transition to decarbonized societies.

\section{ACKNOWLEDGEMENTS}

The author is extremely grateful for the constructive and thoughtful guidance provided by Professor Suzana B. Rodrigues, guest editor, and by the anonymous reviewers. An early version of this manuscript was presented on June 25, 2020 at the Centre for Business and Development Studies (CBDS) and the Institute of Development Studies (IDS) Virtual Seminar Series. I thank Ana Pueyo, Wei Shen, Maribel Blasco, Hans K. Hansen, and Rajiv Maher for their helpful comments regarding earlier versions of this manuscript. This work was supported by the Department of Management, Society and Communication (MSC) at Copenhagen Business School (CBS).

Baker, S. H. 2018. Emerging challenges in the global energy transition: A view from the frontlines. In R. Salter, C. G. Gonzalez, \& E. A. K. Warner (Eds.), Energy justice US and international perspectives: 232-257. Cheltenham: Edward Elgar Publishing.

Bauwens, T. 2016. Explaining the diversity of motivations behind community renewable energy. Energy Policy, 93: 278-290.

Beas-Torres, C. 2012. Tres mitos del megaproyecto eólico del Istmo de Tehuantepec. La Jornada. https://www.jornada. unam.mx/2012/11/03/opinion/023a1est. Accessed 20 October 2013.

Becker, S., Angel, J., \& Naumann, M. 2019. Energy democracy as the right to the city: Urban energy struggles in Berlin and London. Environment and Planning A, 52: 1093-1111.

Becker, S., \& Naumann, M. 2017. Energy democracy: Mapping the debate on energy alternatives. Geography Compass, 11(8): e12321.

Burke, M. J., \& Stephens, J. C. 2018. Political power and renewable energy futures: A critical review. Energy Research \& Social Science, 35: 78-93.

Business \& Human Rights Resource Centre. 2020. Renewable energy \& human rights. https://www.business-humanrights. org/en/renewable-energy-human-rights-analysis. Accessed 17 July 2020. 
Cámara de Diputados del H. Congreso de la Unión. 2011. Constitución política de los Estados Unidos Mexicanos. https://transparencia.uaz.edu.mx/documents/70010/ ea9cb1cb-4cde-4c60-a50c-e2d9ee4bb29b. Accessed 14 July 2019.

Centro de Colaboración Cívico. 2015. 2015. 2013-2015. Historias y aprendizajes sobre el desarrollo de la energía eólica en México. Tehuantepec, Oaxaca. https://colaboracioncivica. org/proyectos/2013-2015-historias-y-aprendizajes-sobreel-desarrollo-de-la-energia-eolica-en-mexico. Accessed 11 November 2016.

Clean Energy Council. 2018. Community engagement guidelines for building powerlines for renewable energy developments. A guide for proponents, landholders and communities. www.cleanenergycouncil.org.au/charter. Accessed 31 October 2019

Copena, D., \& Simón, X. 2018. Wind farms and payments to landowners: Opportunities for rural development for the case of Galicia. Renewable and Sustainable Energy Reviews, 95: 3847.

Doh, J., Rodrigues, S., Saka-Helmhout, A., \& Makhija, M. 2017. International business responses to institutional voids. Journal of International Business Studies, 48(3): 293-307.

Gevorkyan, A. V. 2018. Transition economies: Transformation, development, and society in Eastern Europe and the former Soviet Union. New York: Taylor \& Francis.

Gobierno de México. 2018. Objetivos de desarrollo sostenible. https://www.agenda2030.mx/index.html?lang=es\#/home. Accessed 24 July 2019.

Hernández, A. L., Cerami, A. D. U., Bartolo, F. R., Hernández, L. L., \& Ceballos, X. R. P. 2017. Informe sobre la situación de las personas defensoras de los derechos humanos ambientales en México (2016). Ciudad de México: Centro Mexicano de Derecho Ambiental.

Human Rights Council. 2018. Report of the special rapporteur on the situation of human rights defenders on his mission to Mexico. Geneva. https://www.ohchr.org/EN/HRBodies/HRC/ RegularSessions/Session37/ layouts/15/WopiFrame.aspx? sourcedoc=/EN/HRBodies/HRC/RegularSessions/Session37/ Documents/A HRC 37 51 Add 2 EN.docx\&action=default\& DefaulttemOpen=1. Accessed 11 November 2019.

International Labour Organization. 2017. Ratifications of C169 indigenous and tribal peoples convention, 1989 (No. 169). https://www.ilo.org/dyn/normlex/en/f?p=NORMLEXPUB: 11300:0::NO::P11300 INSTRUMENT ID:312314. Accessed 17 December 2019.

Jenkins, K. 2018. Setting energy justice apart from the crowd: Lessons from environmental and climate justice. Energy Research \& Social Science, 39: 117-121.

Kowszyk, Y., \& Maher, R. 2018. Estudios de caso sobre modelos de Economía Circular e integración de los Objetivos de Desarrollo Sostenible en estrategias empresariales en la UE y ALC. Fundación EU-LAC. https://eulacfoundation.org/es/system/ files/economia_circular_ods.pdf?fbclid=IwAR2R4IK4en07di U4JFDSNFyuJt5buqz60fyTQJeCzhicTmSCzQtbIXeLtl. Accessed 26 June 2020.

Kunze, C., \& Becker, S. 2014. Energy democracy in Europe: A survey and outlook. Rosa Luxemburg Foundation, (January): 63. https://rosalux-europa.info/userfiles/file/Energy-democracyin-Europe.pdf. Accessed 17 August 2020.

Luiz, J. M., Ganson, B., \& Wennmann, A. 2019. Business environment reforms in fragile and conflict-affected states: From a transactions towards a systems approach. Journal of International Business Policy, 2(3): 217-236.

Madriz-Vargas, R., Bruce, A., \& Watt, M. 2018. The future of community renewable energy for electricity access in rural Central America. Energy Research \& Social Science, 35: 118131.

Maher, R. 2019. Pragmatic community resistance within new indigenous ruralities: Lessons from a failed hydropower dam in Chile. Journal of Rural Studies, 68: 63-74.
Manzo, C. 2012. Comunalidad, resistencia y neocolonialismo en el Istmo de Tehuantepec (siglos XVI - XXI). Guadajara: Acento Editores.

Martinez, N. 2020. Resisting renewables: The energy epistemics of social opposition in Mexico. Energy Research \& Social Science, 70: 101632.

McDermott, C. L., Acheampong, E., Arora-Jonsson, S., Asare, R., de Jong, W., Hirons, M., et al. 2019. SDG 16: Peace, justice and strong institutions - a political ecology perspective. In C. J. P. Colfer, G. Winkel, G. Galloway, P. Pacheco, P. Katila, \& W. D. Jong (Eds.), Sustainable development goals: Their impacts on forests and people: 510-540. Cambridge: Cambridge University Press.

Mey, F., \& Diesendorf, M. 2018. Who owns an energy transition? Strategic action fields and community wind energy in Denmark. Energy Research \& Social Science, 35: 108-117.

Olson-Hazboun, S. K., Krannich, R. S., \& Robertson, P. G. 2016. Public views on renewable energy in the Rocky Mountain region of the United States: Distinct attitudes, exposure, and other key predictors of wind energy. Energy Research \& Social Science, 21: 167-179.

Patton, M. Q. 2002. Qualitative research and evaluation methods. Thousand Oaks, CA: Sage.

Peterson, T. R., Stephens, J. C., \& Wilson, E. J. 2015. Public perception of and engagement with emerging low-carbon energy technologies: A literature review. MRS Energy \& Sustainability, 2: E11.

PODER. 2015. Cuarto reporte de la misión de observación sobre el proceso de consulta indígena para la implementación de un proyecto eólico en Juchitán. Oaxaca: Centro De Derechos Humanos.

Presidencia de la República. 2012. El presidente calderón en la inauguración de las centrales eólicas Oaxaca I y la venta III. https://calderon.presidencia.gob.mx/2012/10/el-presidentecalderon-en-la-inauguracion-de-las-centrales-eolicas-oaxaca-iy-la-venta-iii/. Accessed 27 October 2018.

Rothstein, B. 2012. Good governance. In D. Levi-Faur (Ed.), Oxford handbook of governance: 143-154. Oxford: Oxford University Press.

Rubin, J. W. (1994. COCEl in Juchitan: Grassroots radicalism and regional history. Journal of Latin American Studies, 26(1): 109136.

Secretaría de Energía. 2020. El gobierno de México fortalece el sistema eléctrico nacional. https://www.gob.mx/sener/es/ articulos/el-gobierno-de-mexico-fortalece-el-sistema-electriconacional?idiom=es. Accessed 29 July 2020.

Shen, W. 2020. China's role in Africa's energy transition: A critical review of its intensity, institutions, and impacts. Energy Research \& Social Science, 68: 101578.

Sovacool, B. K. 2013. A qualitative factor analysis of renewable energy and Sustainable Energy for All (SE4ALL) in the AsiaPacific. Energy Policy, 59: 393-403.

Sovacool, B. K., \& Dworkin, M. H. 2015. Energy justice: Conceptual insights and practical applications. Applied Energy, 142: 435-444.

Stein, E. 2018. Energy democracy: Power to the people? An introduction. In R. Salter, C. G. Gonzalez, \& E. A. K. Warner (Eds.), Energy justice US and international perspectives: 258274. Cheltenham: Edward Elgar Publishing.

Stephens, J. 2019. Energy democracy: Redistributing power to the people through renewable transformation. Environment: Science and Policy for Sustainable Development, 61: 4-13.

Szulecki, K. 2011. Hijacked ideas: Human rights, peace, and environmentalism in Czechoslovak and Polish dissident discourses. East European Politics and Societies, 25(2): 272-295.

Szulecki, K. 2018. Conceptualizing energy democracy. Environmental Politics, 27(1): 21-41.

The Guardian. 2020. Fifteen people killed in Mexican village linked to windpower dispute. https://www.theguardian.com/ world/2020/jun/23/fifteen-people-killed-in-mexican-villagelinked-to-windpower-dispute. Accessed 6 August 2020. 
Toke, D., Breukers, S., \& Wolsink, M. 2008. Wind power deployment outcomes: How can we account for the differences? Renewable and Sustainable Energy Reviews, 12(4): $1129-1147$.

Ulsrud, K., Winther, T., Palit, D., \& Rohracher, H. 2015. Villagelevel solar power in Africa: Accelerating access to electricity services through a socio-technical design in Kenya. Energy Research \& Social Science, 5: 34-44.

United Nations. 2015a. Transforming our world: The 2030 agenda for sustainable development. Resolution adopted by the general assembly on 25 September 2015. https://www. un.org/en/development/desa/population/migration/general assembly/docs/globalcompact/A_RES_70_1_E.pdf. Accessed 19 June 2018.

United Nations. 2015b. Treaty collections. Chapter XXVII environment 7. d Paris agreement. https://treaties.un.org/Pages/ ViewDetails.aspx?src=TREATY\&mtdsg_no=XXVII-7-d\&chapter $=27 \&$ lang=_en\&clang=_en\#EndDec. Accessed 28 October 2019.

United Nations. 2016a. Goal 7: Ensure access to affordable, reliable, sustainable and modern energy for all. https:// unstats.un.org/sdgs/report/2016/goal-07/. Accessed 19 June 2018.

United Nations. 2016b. Goal 16: Ensure access to affordable, reliable, sustainable and modern energy for all. https://www. un.org/sustainabledevelopment/peace-justice/. Accessed 20 June 2018.

van Tulder, R. 2018. Business \& the sustainable development goals: A framework for effective corporate involvement (RSM series). Rotterdam: Rotterdam School of Management, Erasmus University. hdl.handle.net/1765/110689. Accessed 29 June 2019.

van Veelen, B. 2018. Negotiating energy democracy in practice: Governance processes in community energy projects. Environmental Politics, 27(4): 644-665.

van Veelen, B., \& Eadson, W. 2020. Assembling community energy democracies. Voluntary Sector Review, 11(2): 225-243.

van Veelen, B., \& van der Horst, D. 2018. What is energy democracy? Connecting social science energy research and political theory. Energy Research \& Social Science, 46: 19-28.

van Zanten, J. A., \& van Tulder, R. 2018. Multinational enterprises and the sustainable development goals: An institutional approach to corporate engagement. Journal of International Business Policy, 1(3-4): 208-233.
Velasco-Herrejon, P., \& Bauwens, T. 2020. Energy justice from the bottom up: A capability approach to community acceptance of wind energy in Mexico. Energy Research \& Social Science, 70: 1-15.

Walker, G., \& Devine-Wright, P. 2008. Community renewable energy: What should it mean? Energy Policy, 36(2): 497-500.

Weinrub, A., \& Giancatarino, A. 2015. Toward a climate justice energy platform: Democratizing our energy future. https:// www.localcleanenergy.org/files/Climate Justice Energy Platform.pdf. Accessed 19 May 2018.

Williams, L., \& Sovacool, B. K. 2020. Energy democracy, dissent and discourse in the party politics of shale gas in the United Kingdom. Environmental Politics. https://doi.org/10.1080/ 09644016.2020 .1740555

Wirth, S. 2014. Communities matter: Institutional preconditions for community renewable energy. Energy Policy, 70: 236-246.

Zavala, J. C. 2020. En Oaxaca se produce el $62 \%$ de la energía eólica generada en el país. El Universal, Estatal Oaxaca. https://oaxaca.eluniversal.com.mx/estatal/06-01-2020/enoaxaca-se-produce-el-62-de-la-energia-eolica-generada-en-elpais. Accessed 10 June 2020.

\section{ABOUT THE AUTHOR}

Jacobo Ramirez is an Assistant Professor of Latin American Business Development at Copenhagen Business School (CBS). Ramirez's main research interest is organizational strategy in fragile states and other complex institutional environments facing security risks, displacement, and social unrest. Ramirez's current work focuses on how renewable energy investments affect indigenous peoples' communities and livelihoods. Jacobo Ramirez was born in Mexico to indigenous Mexican parents from the Isthmus of Tehuantepec, and has lived and worked in Copenhagen since 2006.

Publisher's Note Springer Nature remains neutral with regard to jurisdictional claims in published maps and institutional affiliations.

Accepted by Suzana Rodrigues, Guest Editor, 15 September 2020. This article has been with the author for three revisions. 